Kenis, Y., Dustin, P., jun., and Peltzer, T. (1958). Acta Haematologica, 20, 329 Kissmeyer-Nielsen, F., et al. (1973). Histocompatibility Testing 1972, ed. J. Dausset and J. Colombani. Copenhagen, Munksgaard.

Kristensen, M. (1938). Acta Scandinavica Pathologica et Microbiologica, suppl. $37,399$.

Levine P. H., et al. (1971). Cancer, 27, 416.

Levine, P. H., Stevens, D. A., Coccia, P. F., Dabish, L., and Roland, A. (1972). Cancer, 30, 875.
Massey, F. C., Lane, L. L., and Imbriglia, J. E. (1953). Fournal of the American Medical Association, 151, 994.

Miller, G. (1971). Yale Fournal of Biology and Medicine, 43, 358.

Miller, R. W., and Beebe, G. W. (1973). Fournal of the National Cancer Institute, $50,315$.

Rosdahl, N., Olesen Larsen, S., and Thamdrup, A. B. (1973). Scandinavian Fournal of Infectious Diseases, 5, 163.

Smithers, D. W. (1967). British Medical fournal, 2, 337.

\title{
Prevalence of Hepatitis B Antigen and Antibody in Prostitutes
}

\author{
G. PAPAEVANGELOU, \\ D. TRICHOPOULOS, \\ T. KREMASTINOU, \\ G. PAPOUTSAKIS
}

British Medical fournal, 1974, 2, 256-258

\section{Summary}

We investigated the prevalence of hepatitis $B$ antigen (HBAg) and antibody (HBAb) in 293 prostitutes and in 379 pregnant women of similar age and of low socioeconomic level, who served as controls. HBAg was found in $4.4 \%$ of prostitutes and $3.4 \%$ of controls. The prevalence of $\mathrm{HBAb}$ was significantly higher $(P<0.001)$ in prostitutes $(56 \cdot 7 \%)$ than in controls $(24 \cdot 5 \%)$. The prevalence of HBAb was clearly age-dependent in both groups. Evidence of hepatitis $B$ virus infection significantly increased with the number of years in prostitution. The evidence of increased infection rates among prostitutes and their distribution support the hypothesis that hepatitis B infection is sexually transmitted.

\section{Introduction}

Recent studies suggest that hepatitis B may be transmitted by non-parenteral or at least inapparent routes (Cossart, 1971) and that sexual transmission may play an important role in the spread of the disease (Jeffries et al., 1973). Thus a high rate of infection might be expected among prostitutes. We therefore decided to test this hypothesis by studying the prevalence of hepatitis B antigen (HBAg) and antibody (HBAb) in prostitutes in Athens, where the incidence of hepatitis B virus infection is high (Papaevangelou et al., 1971). We report the results of the study in this paper.

\section{Subjects and Methods}

The study sample consisted of 293 registered prostitutes in the Greater Athens area. Their age, length of time in prostitution, and history of syphilis were ascertained by direct questioning and from the special records of regular medical examinations. An unselected sample of 379 pregnant women who were delivered in hospital served as controls. Nearly all of them were in social class IV or V (General Register Office, 1951). The age range of the prostitutes was 20-51 years (mean $30 \cdot 1$ ), which

\footnotetext{
Department of Hygiene and Epidemiology, School of Medicine, University of Athens, Athens 609, Greece

G. PAPAEVANGElOU, M.D., Associate Professor of Hygiene and Epi-

D. TRICHOPOULOS, M.D., Professor and Chairman, Department of Hygiene and Epidemiology

T. KREMASTINOU, M.D., Lecturer in Hygiene and Epidemiology G. PAPOUTSAKIS, M.D., Lecturer in Hygiene and Epidemiology
}

was slightly but not significantly $(P>0 \cdot 1)$ higher than that of the controls (mean age $27 \cdot 7$ years).

Blood samples were allowed to clot and the separated serum was stored at $-20^{\circ} \mathrm{C}$. Screening for $\mathrm{HBAg}$ was done by counterimmunoelectrophoresis (Pesendorfer et al., 1970) and immunodiffusion test (Prince, 1968); for $\mathrm{HBAb}$ by passive haemagglutination assay (Vyas and Shulman 1970); for syphilis by Wasserman as well as by R.P.R.* card test; and for SGPT by a modified method of Reitman-Frankel (1957). Differences between frequency rates were tested by $\chi^{2}$ test with Yates's correction.

\section{Results}

HBAg was present in $13(4.4 \%)$ of the prostitutes and in 13 $(3.4 \%)$ of the controls (table I, fig. 1). This difference was not statistically significant $(P>0 \cdot 1)$. In two of the $\mathrm{HBAg}$-positive prostitutes and one of the controls SGPT levels were above normal but not higher than 100 Karmen units. HBAg was more prevalent in prostitutes than in controls in almost all age groups. There was also a definite tendency for the $\mathrm{HBAg}$ prevalence to decrease with age in both prostitutes and controls. HBAg when found was still present in all cases on retesting at least six months later, but in no case was HBAb present.

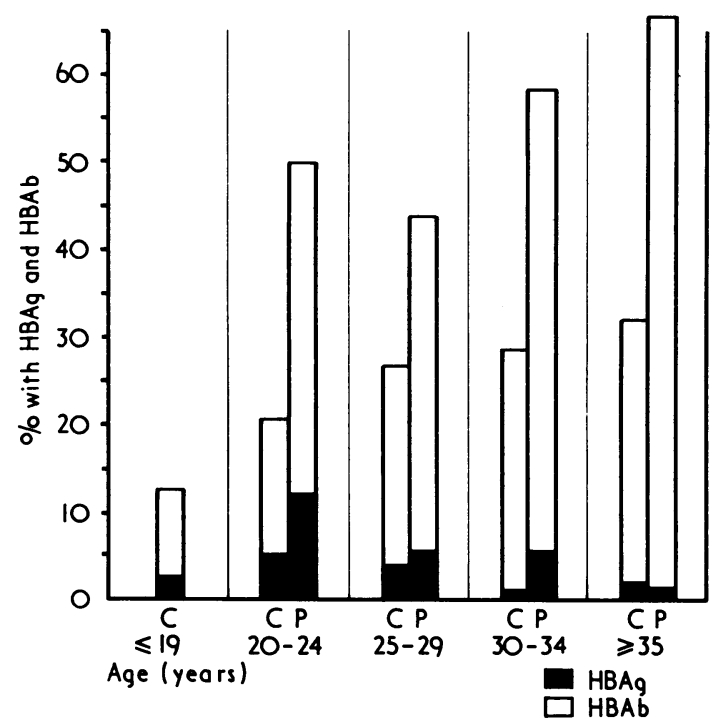

FIG. 1-Prevalence of bepatitis $B$ antigen (HBAg) and antibody (HBAb) among prostitutes $(P)$ and pregnant women (C) in relation to age.

*Hynson, Westcoff and Dunning, Inc., Baltimore, Maryland, U.S.A. 
TABLE 1-Prevalence of Hepatitis B Antigen (HBAg) and Antibody (HBAb) among Prostitutes and Controls

\begin{tabular}{|c|c|c|c|c|c|c|c|c|c|c|c|c|c|c|}
\hline \multirow{3}{*}{ Age Group } & \multicolumn{7}{|c|}{ Controls } & \multicolumn{7}{|c|}{ Prostitutes } \\
\hline & \multirow{2}{*}{ No. } & \multicolumn{2}{|c|}{ HBAg } & \multicolumn{2}{|c|}{ HBAb } & \multicolumn{2}{|c|}{ HBAg or HBAb } & \multirow{2}{*}{ No. } & \multicolumn{2}{|c|}{ HBAg } & \multicolumn{2}{|c|}{ HBAb } & \multicolumn{2}{|c|}{ HBAg or HBAb } \\
\hline & & Positive & $\%$ & Positive & $\%$ & Positive & $\%$ & & Positive & $\%$ & Positive & $\%$ & Positive & $\%$ \\
\hline $\begin{array}{l}\leqslant 19 \\
20-24 \\
25-29 \\
30-34 \\
\geqslant 35\end{array}$ & $\begin{array}{r}33 \\
115 \\
106 \\
81 \\
44\end{array}$ & $\begin{array}{l}1 \\
6 \\
4 \\
1 \\
1\end{array}$ & $\begin{array}{l}3.0 \\
5.2 \\
3.8 \\
1.2 \\
2.3\end{array}$ & $\begin{array}{r}4 \\
24 \\
28 \\
23 \\
14\end{array}$ & $\begin{array}{l}12.1 \\
20.9 \\
26.4 \\
28.4 \\
31.8\end{array}$ & $\begin{array}{r}5 \\
30 \\
32 \\
24 \\
15\end{array}$ & $\begin{array}{l}15 \cdot 2 \\
26 \cdot 1 \\
30 \cdot 2 \\
29 \cdot 6 \\
34 \cdot 1\end{array}$ & $\begin{array}{r}\overline{18} \\
73 \\
57 \\
138\end{array}$ & $\begin{array}{l}-2 \\
4 \\
3 \\
2\end{array}$ & $\begin{array}{r}1 \overline{11.1} \\
5.5 \\
5.3 \\
1.5\end{array}$ & $\begin{array}{r}-9 \\
32 \\
33 \\
91\end{array}$ & $\begin{array}{l}5 \overline{50.0} \\
43.8 \\
57.9 \\
65.9\end{array}$ & $\begin{array}{l}\overline{11} \\
36 \\
36 \\
93\end{array}$ & $\begin{array}{l}6 \overline{1 \cdot 1} \\
49 \cdot 3 \\
63 \cdot 2 \\
67 \cdot 4\end{array}$ \\
\hline Total & 379 & 13 & $3 \cdot 4$ & 93 & $24 \cdot 5$ & 106 & $28 \cdot 0$ & 293* & 13 & 4.4 & 166 & 56.7 & 179 & $61 \cdot 1$ \\
\hline
\end{tabular}

*Age unknown in seven (two HBAg positive and one HBAb positive).

TABLE II-Prevalence among Prostitutes of Hepatitis B Antigen (HBAg) and Antibody (HBAb) by Years in Prostitution

\begin{tabular}{|c|c|c|c|c|c|c|c|}
\hline \multirow{2}{*}{ Years in Prostitution } & \multirow{2}{*}{ No. } & \multicolumn{2}{|c|}{ HBAg } & \multicolumn{2}{|c|}{ HBAb } & \multicolumn{2}{|c|}{ HBAg or HBAb } \\
\hline & & Positive & $\%$ & Positive & $\%$ & Positive & $\%$ \\
\hline $\begin{array}{l}<1 \\
1-2 \\
3-4 \\
\geqslant 5\end{array}$ & $\begin{array}{r}29 \\
30 \\
26 \\
178\end{array}$ & $\begin{array}{l}1 \\
4 \\
3 \\
3\end{array}$ & $\begin{array}{r}3.5 \\
13.3 \\
11.5 \\
1.7\end{array}$ & $\begin{array}{r}11 \\
13 \\
16 \\
115\end{array}$ & $\begin{array}{l}37.9 \\
43.3 \\
61.5 \\
64.6\end{array}$ & $\begin{array}{r}12 \\
17 \\
19 \\
118\end{array}$ & $\begin{array}{l}41.4 \\
56.7 \\
73.1 \\
66.3\end{array}$ \\
\hline Total & 293* & 13 & 4.4 & 166 & 56.7 & 179 & $61 \cdot 1$ \\
\hline
\end{tabular}

-Duration in prostitution unknown in 30 (two $\mathrm{HBAg}$ positive and $11 \mathrm{HBAb}$ positive).

HBAb was present in 166 of the prostitutes $(56.7 \%)$ and in $93(24.5 \%)$ of the controls (table I, fig. 1). The difference was significant $\left(\chi^{2}=70.6 ; P<0.001\right)$. The prevalence among controls under 20 years old was $12 \cdot 1 \%$. It increased rapidly with age, reaching $31 \cdot 8 \%$ among women over 35 years old. The increase with age was less appreciable in prostitutes, the corresponding rates being $50 \%$ in the $20-24$ age group and $65.9 \%$ in those over 35 years old. Thus in both groups the prevalence of $\mathrm{HBAb}$ was age dependent.

When the prevalences of HBAg and HBAb were related to years in prostitution a substantially higher rate of $\mathrm{HBAg}$ was noted in prostitutes in their first five years of prostitution (table II, fig. 2). It decreased substantially in those who had been in prostitution more than five years. The prevalence of HBAb was directly related to the duration of prostitution. It was present in $37.9 \%$ of those who had been in prostitution for less than one year and in $64.6 \%$ of those who had been in it for over five years. This difference was slightly accentuated after standardization for age (corresponding rates $28 \cdot 1 \%$ and $72 \cdot 4 \%$ ).

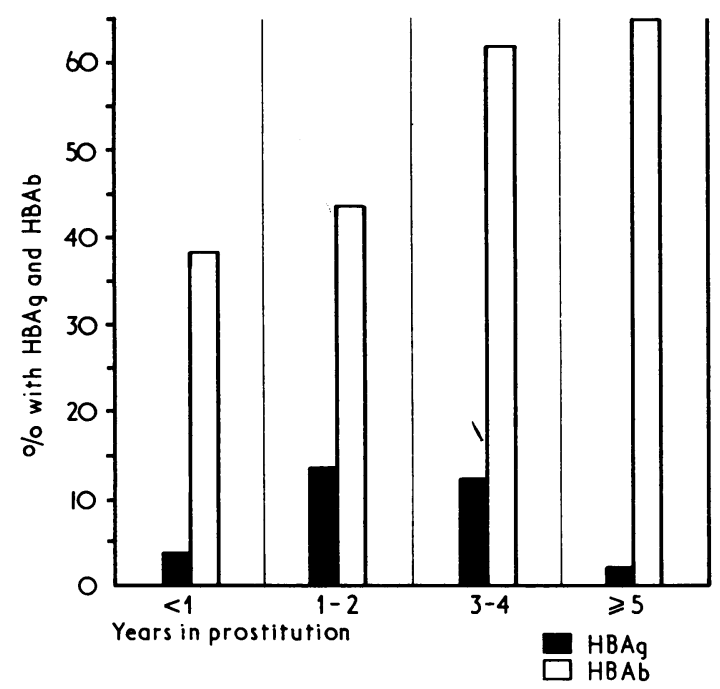

FIG. 2-Prevalence among prostitutes of hepatitis $\mathrm{B}$ antigen (HBAg) and antibody (HBAb) according to years in prostitution.
Serological evidence of syphilis was present in or recorded in the history of $\mathbf{4 5}$ prostitutes. $\mathrm{HBAg}$ was detected in three $(6.7 \%)$ and HBAb in $27(60 \%)$ of them. These rates were not statistically higher $(\mathrm{P}>0.1)$ than those of $\mathrm{HBAg}(4 \%)$ or $\mathrm{HBAb}$ $(56 \%)$ in prostitutes without evidence of syphilis.

\section{Discussion}

Transmission of hepatitis B to sexual partners has been reported (Hersh et al., 1971, Heathcote and Sherlock, 1973). HBAg is found more often in young adults (Prince et al., 1970) and the carrier rate is high in homosexuals (Vahrman, 1973), in patients attending venereal disease clinics (Jeffries et al., 1973), and in prostitutes (Papaevangelou et al., 1973). HBAg carrier rates are not an index of cumulative past experience of hepatitis B (Blumberg et al., 1969, Szmuness et al., 1973). In contrast HBAb prevalence rates reflect past exposure to hepatitis B virus and therefore they provide reliable information from which to draw conclusions. Fulford et al. (1973) reported that promiscuity increases the incidence of HBAb. Their sample consisted of patients attending a clinic for sexually transmitted diseases and HBAb was detected by the insensitive inmunodiffusion technique.

In the present study the highly sensitive method of passive haemagglutination assay was used to show the presence of $\mathrm{HBAb}$ in prostitutes, who may be considered as the group with the highest risk of contracting sexually transmitted diseases. The findings were compared with a sample of pregnant women of a low socioeconomic level and of roughly comparable age. The results showed that evidence of hepatitis $B$ virus infection (prevalence of HBAg or HBAb) was significantly higher in the prostitutes. As expected, evidence of infection was related to age in both groups. The higher prevalence among the younger prostitutes may be explained by, among other things, the practice of illegal prostitution, which is usual for a time before registering as a prostitute.

Age and duration of prostitution are closely correlated. Therefore the increase seen in the hepatitis $B$ infection rates with the duration of prostitution could be partly attributed to differences in the ages of the prostitutes concerned. Standardization for age scarcely affected the duration gradient of the infection rates. Therefore the duration effect is probably independent of the age effect. These findings are further evidence for the sexual transmission of hepatitis $B$. 
Increased exposure to hepatitis B virus by other than the sexual route may be expected in prostitutes. Transmission by the parenteral route as a result of drug addiction may be more common in prostitutes. None in our sample had a history of parenteral drug abuse, which is very rare in Greece (Adjutantis, 1973). Treatment for syphilis, gonorrhea, and other infections may be other vehicles for parenteral transmission, but evidence of hepatitis B infection was no greater among the prostitutes with syphilis in our sample. Thus these factors do not seem to explain the great difference in prevalence rates between the prostitutes and controls in our study. We believe that the distribution of evidence of hepatitis B virus infection in the prostitutes in our study is compatible with a venereal mode of transmission. Other carefully controlled studies would, we hope, confirm our findings and provide further support for our belief.

This study was supported in part by a grant from the office of Scientific Research and Development, Ministry of Culture and Sciences.

\section{References}

Adjutantis, G. (1973). Minerva Medica Greca, 1, 119

Blumberg, B. S., Sutnick, A. T., and London, T. (1969). Fournal of the American Medical Association, 207, 1895.

Cossart, Y. (1971). Fournal of Clinical Pathology, 24, 394.

Fulford, K. W., Dane, D. S., Catteral, R. D., Woof, R., and Denning, J. V. (1973). Lancet, 1, 1470.

General Register Office. (1951). Classification of Occupations, 1950. London, H.M.S.O.

Heathcote, J., and Sherlock, S. (1973). Lancet, 1, 1468.

Hersh, T., Melnick, J., Goyal, R. K., and Hollinger, F. B. (1971). New England fournal of Medicine, 285, 1363.

Jeffries, D. J., James, W. H., Jefferiss, F. J. G., Macleod, K. G., and Willcox, R. R. (1973). British Medical fournal, 2, 455.

Papaevangelou, G., Kourea, T., and Tsoukas, S. (1971). Pathologia et Microbiologia, 37, 361 .

Papaevangelou, G., Trichopoulos, D., Papoutsakis, G., Kremastinou, T., and Pavlides, E. (1973). Ninth International Congress on Tropical Medicine and Malaria. Abstracts, 2, 166.

Pesendorfer, F., Krassnitzky, O., and Wewalka, F. (1970). Klinische Wochenschrift, 48, 58 .

Prince, A. M. (1968). Proceedings of the National Academy of Sciences of the United States of America, 60, 814.

Prince, A. M., et al. (1970). New England fournal of Medicine, 282, 987.

Reitman, S., and Frankel, S. (1957). American fournal of Clinical Pathology, 20, 56.

Szmuness, W., Prince, M., Brotman, B., and Hirsch, R. (1973). Fournal of Infectious Diseases, 127, 17.

Vahrman, J. (1973). Lancet, 2, 157.

Vyas, G. N., and Shulman, N. R. (1970). Science, 170, 332.

\section{PRELIMINARY COMMUNICATIONS}

\section{"Anticonvulsant Action" of Vitamin $D$ in Epileptic Patients? A Controlled Pilot Study}

\author{
CLAUS CHRISTIANSEN, PAUL R $\varnothing$ DBRO, \\ OLE SJÖ
}

British Medical fournal, 1974, 2, 258-259

\section{Summary}

The frequency of epileptic seizures was observed in a controlled therapeutic trial on 23 epileptic inpatients before and after treatment with vitamin $D_{2}$ or placebo in addition to anticonvulsant drugs. The number of seizures was reduced during treatment with vitamin $D_{2}$ but not with placebo. The effect was unrelated to changes in serum calcium or magnesium. The results may support the concept that epileptics should be treated prophylactically with vitamin $D$.

\section{Introduction}

Minor degrees of hypocalcaemia (Richens and Rowe, 1970; Christiansen et al., 1973) and hypomagnesaemia (Christiansen et al., 1974) are known to occur in epileptics on anticonvulsant therapy. As a lowering of the concentration of these ions in extracellular fluid would tend to increase neuromuscular irritability it is conceivable that the effect of anticonvulsants could be partially counteracted. These biochemical changes are part of an osteomalacic state in such patients, and since small doses of vitamin $\mathrm{D}$ can increase the bone mineral content

\section{Department of Clinical Chemistry, Glostrup Hospital, 2600 Glostrup, Denmark \\ CLAUS.CHRISTIANSEN, CAND. MED., Assistant Physician \\ OLE SJÖ, CAND. MED., Assistant Physician}

Department of Clinical Physiology, Aalborg Sygehus Syd, 9000 Aalborg, Denmark

PAUL RøDBRO, M.D., Physician-in-Chief
(Christiansen et al., 1973) it is possible that vitamin D might also influence the number of epileptic fits. For practical purposes the problem might be reformulated in the following way: Does vitamin $\mathrm{D}$ reduce the number of seizures in epileptic patients on anticonvulsant therapy? We report here the results of a controlled pilot study which seem to indicate that this may be the case.

\section{Patients and Methods}

Altogether 23 epileptic inpatients who had relatively frequent fits were selected for the study (table I). All the patients originally had typical grand mal or focal motor attacks and several of them also had other types of seizure. Since they were receiving various combinations of phenytoin, phenobarbitone, and primidone, for the purpose of analysis dosage (table 1) was calculated according to the data of Richens and Rowe (1970).

The number and type of seizures were recorded by experienced nurses who were unaware whether the patient was receiving vitamin D or placebo. Grand mal, abortive forms of grand mal as seen in patients on anticonvulsant treatment, and focal motor seizures were recorded.

TABLE I-Details of Patients and Dose and Duration of Anticonvulsant Treatment. Patients were divided into Two Treatment Groups (see text)

\begin{tabular}{|c|c|c|c|c|c|c|c|c|c|}
\hline \multirow[t]{2}{*}{ Group } & \multirow[t]{2}{*}{$\begin{array}{c}\text { No. of } \\
\text { Patients }\end{array}$} & \multicolumn{2}{|c|}{ Sex } & \multicolumn{2}{|c|}{ Age (Years) } & \multicolumn{2}{|c|}{$\begin{array}{l}\text { Daily Dose of } \\
\text { Anticonvulsant } \\
\text { (Units*) }\end{array}$} & \multicolumn{2}{|c|}{$\begin{array}{l}\text { Duration of } \\
\text { Anticonvulsant } \\
\text { Treatment } \\
\text { (Years) }\end{array}$} \\
\hline & & M. & F. & Mean & Range & Mean & Range & Mean & Range \\
\hline $\begin{array}{l}\mathbf{A} \\
\mathbf{B}\end{array}$ & $\begin{array}{r}9 \\
14\end{array}$ & $\begin{array}{r}4 \\
11\end{array}$ & $\begin{array}{l}5 \\
3\end{array}$ & $\begin{array}{l}15 \\
13\end{array}$ & $\begin{array}{l}9-27 \\
6-25\end{array}$ & $\begin{array}{l}6.9 \\
6 \cdot 0\end{array}$ & $\begin{array}{l}2-11 \\
3-12\end{array}$ & $\begin{array}{l}11 \\
11\end{array}$ & $\begin{array}{l}3-23 \\
5-17\end{array}$ \\
\hline
\end{tabular}

*Dose calculated in units according to data of Richens and Rowe (1970).

Blood samples were drawn for the determination of serum calcium, serum magnesium, and serum alkaline phosphatase. These determinations, all in duplicate, were performed as previously reported (Christiansen et al., 1973, 1974).

Procedure. - The patients were allocated to two treatment groups (A and B, see table I) by means of random sampling numbers (Bradford Hill, 1967). The duration of the trial was 84 days and it was divided into three periods of 28 days. The 